The total removal of the larynx (total laryngectomy), performed in 1872 by the well-known Viennese surgeon Christian A. Theodor Billroth (1829-1894), was an epoch-making event in the history of surgery and laryngology. This paper presents the first surgeons who performed this operation. The first Pole who performed a total laryngectomy (1877) was Julian Kosiński (1833-1914), head of the Surgical Clinic of Imperial University Warsaw. It was the $14^{\text {th }}$ operation of this kind in the world. Several laryngectomies were carried out by Franciszek Ksawery Jawdyński (1851-1896), called the father of Polish head and neck surgery, who was the first Pole to excise a malignant neck cancer together with the lymph nodes. The next total laryngectomies were performed by the following Polish surgeons: Jan Mikulicz-Radecki (18501905), Władysław H.S. Krajewski (18551907), Alfred Obaliński (1843-1898). According to Jan Sędziak, by 1897 Poland with 16 laryngectomies (per 188 carried out) had occupied the fourth position in the world. The failures of the first laryngectomies were due to such factors as the ignorance of shock pathophysiology, the inability to ensure the patency of the airways during and after the operation, which would result in lung and mediastinum infections, massive haemorrhages and so on. But the primary cause was the lack of constructive collaboration between the laryngologists and the surgeons.

Key words: history of laryngology, history of surgery, total laryngectomy.

Contemp Oncol (Pozn) 2013; 17 (6): 473-476 DOI: $10.5114 /$ wo.2013.38908

\section{The first Polish total laryngectomies}

\author{
Andrzej Kierzek, Małgorzata Paprocka-Borowicz, Andrzej Pozowski, \\ Jadwiga Kuciel-Lewandowska
}

Department of Physiotherapy, Wrocław Medical University of Silesian Piasts, Wrocław, Poland

Total laryngectomy (laryngectomia totalis) consists in the removal of the larynx, together with the hyoid bone and the epiglottic space, by severing it from the trachea, the tongue base, the throat and the oesophagus. Subsequently, the tracheal stump is anastomosed to the neck skin and the throat's split laryngeal part and the oesophagus are closed. As a result, the alimentary tract and the respiratory tract are totally separated and a permanent tracheostomy becomes necessary [1].

"When Billroth four years ago in Vienna for the first time excised the entire cancerous larynx from a living human being and in this way prolonged the sick person's life, this caused, not only in the medical world, but one can say in the whole world, such a sensation as, it seems, no surgical operation before had managed to create" in 1877 wrote Julian Kosiński (1833-1914) - one of the most outstanding Polish surgeons of the $19^{\text {th }}$ century, head of the Surgical Clinic of the Imperial University of Warsaw [2, 3]. Thanks to improvements in the operative technique, the introduction of general anaesthesia and the development of pathologic anatomy the range of surgical measures was quickly widening in the second half of that century [4].

Christian Albert Theodor Billroth (1829-1894), a pupil of Bernhard Rudolph van Langenbeck (1810-1887), professor of surgery in Vienna and one of the most outstanding surgeons in history, diagnosed a 36-year-old religion teacher with laryngeal carcinoma located under the vocal cords, on one side of the thyroid cartilage. The condition was confirmed by Carl S. Stoerck (1832-1896) - one of the founders of world rhinolaryngology. At the end of November 1873, Billroth, having introduced a cannula with a sealing inflatable Trendelenburg balloon into the trachea, performed a tracheotomy under general chloroform anaesthesia. A week after the tracheotomy Billroth performed a laryngofissure. After the tumour was removed, the surface from which it originated was scraped out with a sharp curette. Because of the recurrence of the disease process Billroth had to intervene further. Initially, he intended to perform a laryngofissure again and "vigorously scrape out the tumour". However, because of the considerable expansion of the tumour he changed his decision. Having obtained the patient's consent, on the $31^{\text {st }}$ of December of the same year (1873) he performed a total laryngectomy - the first in the history of medicine. He did not remove the neck lymph nodes and reduced the resulting throat loss with three sutures [5]. After the operation, accompanied by considerable bleeding, the patient was fed through a stomach tube. Two months after the operation, the patient, equipped with an artificial larynx designed by Gussenbauer, was presented at a meeting of the Viennese Medical Society and on the $3^{\text {rd }}$ of March he left the clinic. Carl Gussenbauer (1842-1903), a pupil of Billroth, when performing a laryngoscopy on the patient indicated a suspicion of the beginning of a recurrence. A few months later as a result of cancer relapse the patient passed away [6].

The date of the first laryngectomy in history marked an epoch-making event in the history of laryngology. Jan Sędziak (1861-1932), a Warsaw otorhinolaryngologist, well known in Anglo-Saxon countries, in his epoch-making work "Die bösartigen Geschwülste des Kehlkopfes und ihre Radicalbehandlung" (Wiesbaden 1897), which is still used today by historians of laryngology, 


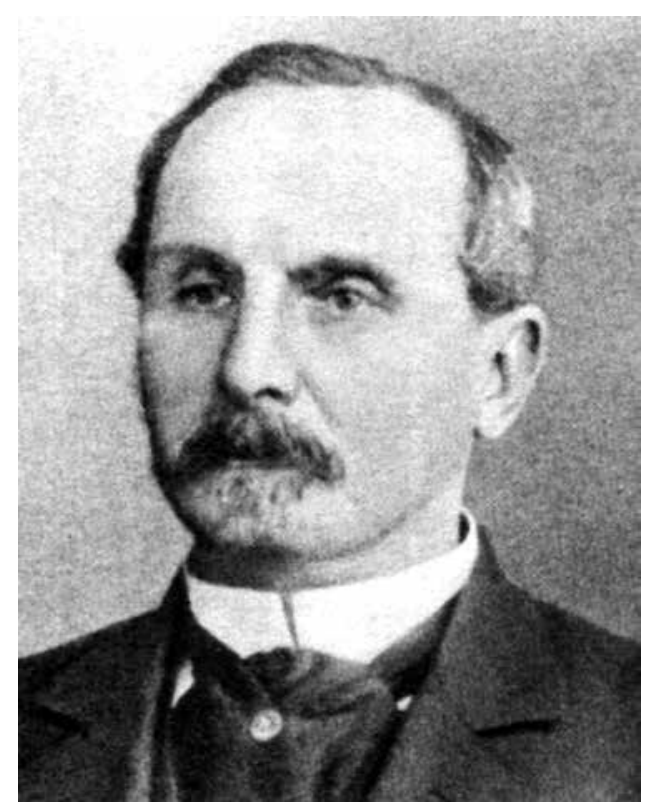

Fot. 1. Julian Kosiński (1833-1914). In: the Special Collection of the Main Medical Library, neg. 46/507

wrote: "In the history of cancer of the larynx the day of the $31^{\text {st }}$ of December 1873 will always be remembered" $[4,7]$.

Probably this operation, technically difficult in those times, Billroth's surgical finesse in which was admired, would not have gained so much publicity if it had not been performed by this Viennese virtuoso of surgery, also a music critic and composer, and a friend of Johannes Brahms.

Billroth's total laryngectomy initiated a series of such operations in the case of larynx cancer - which was then considered incurable. Imitators appeared. On the $15^{\text {th }}$ of April 1874 Bernhard Heine from Prague performed this operation on a patient who six months later died because of relapse. The third operation was performed in June the same year by Hermann M. Mass in Wrocław; the 56-yearold patient died on the $14^{\text {th }}$ day as a result of pneumonia. The fourth operation was performed also in 1874 by Moritz Schmidt from Frankfurt; the 56-year-old patient died as a result of collapse. The fifth operation was performed by Enrico Bottini in Navarre on the $6^{\text {th }}$ of February 1875; he operated on a young patient who six months after the operation enjoyed quite good health [8-13].

The list of Polish laryngectomists is headed by the already mentioned Julian Kosiński. The operation was performed on the $15^{\text {th }}$ of March 1877, on a 36-year-old woman whose entire larynx together with the epiglottis was affected by cancer. According to Sędziak, it was the $14^{\text {th }}$ total laryngectomy in history. The patient died nine months later because of the recurrence of the cancer. Kosinski performed another laryngectomy in 1800, on a 50-year-old man whose entire larynx was affected by cancer. Massive pneumonia on the fourth day after the operation terminated the patient's life. On the $19^{\text {th }}$ of November 1886 Kosiński performed the next laryngectomy, this time on a 62-yearold man with cancer affecting his entire larynx. Pneumonia was the cause of the patient's death due to cancerous cachexia, eleven weeks after the operation $[2,14]$.
Franciszek Jawdyński (1851-1896), one of the most talented $19^{\text {th }}$ century Warsaw surgeons, the father of Polish head and neck surgery, is known in Polish surgery for being the first to perform, in 1888, an operation for the removal of a neoplastic tumour in the neck of a 70 -yearold patient, simultaneously removing not only the sternocleidomastoid muscle, but also the internal carotid vein, a $6 \mathrm{~cm}$ long segment of the common and internal carotid artery, and the neck lymph nodes, without injuring the vagus nerve. The tumour was identified as Volkmann's branchial cancer (now known as carcinoma branchiogenes), without indicating the primary focus. Stanisław Bien, an outstanding contemporary laryngologist and oncologist, thinks that it is difficult to objectively concede that linking Jawdyński's name with the radical operation for the removal of the neck lymph nodes, so meticulously described by George Washington Crile (1864-1934) in 1906, is justified. On the $6^{\text {th }}$ of November 1885 Jawdyński operated on the cancer affected larynx and a part of the throat in a 63-year-old woman, who died 10 months after the operation because of relapse. Then Jawdyński carried out four more total laryngectomies. In 1890 he performed a laryngectomy in a 68-year-old patient with a tumour in the arytenoid region, who, nevertheless, died due to relapse 16 months after the operation. In September next year in a 48-year-old patient, in poor general condition, with tonsil carcinoma affecting the entire side of the throat and extending onto the larynx in the piriform recess region, he performed a laryngectomy with a ligation of the internal carotid artery and the carotid vein. The fate of the patient was not hard to predict. Nor did a 45-year-old patient with neoplastic ulceration of the larynx, who had the upper part of the trachea and half of the thyroid gland removed, have any chances - he died a few hours after the operation, as a result of shock after a massive haemorrhage. In 1892 Jawdyński performed another laryngectomy; the 65-yearold patient died 6 weeks after the operation. This talented surgeon preferred tracheostomy simultaneously combined with the principal removal operation. The introduction of a feeding tube via temporary pharyngostomy, closed after ten-twenty days, is worth noting [7, 15-19].

In 1886 two total laryngectomies were performed by Jan Mikulicz-Radecki (1850-1905), a pupil of Billroth, an authority on gastroenterological surgery, then professor of surgery at the Jagiellonian University. In both cases, the tumour affected the entire larynx. In the first case, death occurred after a few months, due to cancerous cachexia, and in the second case, after merely a few weeks [7].

Another Polish doctor who carried out total laryngectomy was Władysław Henryk Seweryn Krajewski (18551907), head of the Surgical Department of the Baby Jesus Hospital in Warsaw. In December 1887 he removed the entire larynx together with the epiglottis in a 51-year-old male patient (a peasant) who died, due to pneumonia, 9 months after the operation. A few weeks before death, metastases in the lymph nodes had been found. Krajewski together with Władysław Wróblewski (1860-1906), a well-known Warsaw practitioner laryngologist, in 1889 published in several consecutive issues of Medicine an extremely interesting paper entitled "Laryngeal Carcinoma. 
Total Laryngectomy", in which, besides the history of such operations performed by then, he presented interesting observations on an improvement in treatment results owing to the introduction of antisepsis and the more precise tamponing of the trachea. In 1894 he removed the entire larynx together with the adjoining part of the throat in a 58-year-old male patient. The latter survived for only 10 days [20].

Total laryngectomies were also carried out by Alfred Obaliński (1843-1898), head of the Surgical Department of the St. Lazarus Hospital, later (from 1897) head of the Surgical Clinic of the Jagiellonian University. In 1893 in "the diary of the St. Lazarus Hospital Surgical Department" he described three cases. In August 1889 in a 50-year-old male patient with half of his larynx affected by cancer, having previously performed a tracheotomy and an exploratory laryngofissure, he carried out a laryngectomy. A haemorrhage was the cause of death sixteen days after the operation. In March 1890 in a 49-year-old man with cancer in the scar after the previous laryngofissure, he also performed a total laryngectomy; four and a half year long observation did not show a recurrence of the process. In September 1891 in a 42-year-old man with a cauliflower-like tumour in half of the larynx, having previously performed an intralaryngeal procedure and a laryngofissure, he performed a total laryngectomy, after which the patient three years later felt well and "even could sing". In May 1894 he performed another operation of this kind on a 57-year-old patient with a tumour in the piriform recess and on the vocal folds. Nearly three months long postoperative observation after the operation showed no recurrence [7].

Jan Sędziak acquired the knowledge on the achievements of the Polish surgeons performing total laryngectomies from the available medical literature as well as from letters written by the particular Polish surgeons, addressed to him and not published anywhere later.

It is surprising that no indications for total laryngectomy had been specified by the end of the $19^{\text {th }}$ century. The present authors did not come across them in the publications available to them.

As stated by Jan Sędziak in the work cited above, in the first twenty years of performing total laryngectomies, three-year cures were obtained in only $5.85 \%$ of the patients, at a high surgical mortality of $44.7 \%$ [7]. To sum up, by the year 1897 because of cancer 188 total laryngectomies had been carried out in the world [6]. Polish doctors performed this operation in 16 cases, which put them in the fourth position in the world (Germany - 49 cases, Italy - 19, Austria - 18). The Poles had outdistanced the doctors in the UK, the USA, Denmark, Switzerland and Russia [21]. The analysis of all the 188 total laryngectomies performed in this paper shows that the achievements of the Polish doctors generally were the equal of those of doctors of other nationalities.

Jan Miodoński (1902-1963), an outstanding Cracow otolaryngologist, and his collaborators M. Spritzer and Antoni F. Wadon, when analyzing the failures of the first laryngectomies, which were disapproved of by English doctors who considered them to be inhuman operations causing terrible disability and so unacceptable, rightly not- ed the achievements of Glück, both a brilliant operating surgeon and a phoniatrist, and his pupil Sörensen, who, trying to maximally save the voice, proposed partial laryngectomies [22].

Analyzing the failures of the first surgeons performing total laryngectomies, the authors of this paper have come to the inescapable conclusions which Jacek Składzien and Eugeniusz Olszewski, outstanding clinicians, heads of the Otolaryngological Clinic of the Jagiellonian University, presented in their paper published in the journal Polish Otolaryngology. The considerable risk of perioperative death as a result of the total removal of the larynx was mainly due to: the ignorance of shock pathophysiology, the considerable loss of blood and the impossibility of making it up, the inability to ensure the patency of the airways during and after the operation, which would result in lung infections leading to massive pneumonias, the occurrence of wound infections accompanied by necrosis of the skin and the deeper situated tissues, and suppuration making throat closure impossible and leading to infections of the mediastinum and the lungs or to fatal haemorrhages. In those days no removal of the neck lymph nodes concurrent with the operation on the larynx was performed [23]. There were no effective anti-inflammatory drugs which would effectively counteract the often massive inflammatory conditions. "Partial" resections of the larynx, to which a separate paper will be devoted, were much safer in such morbidities.

In those times there was no collaboration between laryngologists and surgeons. The former had no operative experience or proper surgical skills and usually limited themselves to diagnosis and minor surgical procedures. Major operations were performed exclusively by surgeons. This was the situation in the whole $19^{\text {th }}$ century medical world. Considering the conditions in $19^{\text {th }}$ century surgery, the relatively small number of severe complications connected with surgical treatment is notable [23, 24].

The fulfilment of the postulates mentioned in this paper's conclusion, the intensive development of diagnostic and operative methods, the optimization of the indications, the better understanding of the biology of cancers, molecular research, the use of novel anti-inflammatory agents, combined treatment, safer radiotherapy and chemotherapy, the multifaceted training of specialists in laryngology, medical inter-specialization collaboration, drawing on the achievements of other branches of learning, and several other factors contribute to the increasingly more effective treatment of malignant laryngeal cancers.

\section{The authors declare no conflict of interests.}

\section{References}

1. Latkowski B. The technique of procedures and operations in oto-rhino-laryngology (in Polish). Warsaw 2000.

2. Kosiński J. A case of total laryngectomy (in Polish). Pam Tow Lek, Warsaw 1877; 73: 493.

3. Rudowski W, Śródka A. Register of Polish surgeons (in Polish). Wrocław, Warsaw, Kraków, Gdańsk, Łódź 1990; 130.

4. Olszewski E. On the centenary of the first laryngectomy (in Polish). Otolaryng Pol 1975; 29: 185. 
5. Składzień J, Olszewski E. The development of surgical treatment of laryngeal cancer (in Polish). Otolaryng Pol 1995; 49: 4.

6. Gussenbauer C. Ueber die erste durch Th. Billroth am Menschen ausgefuhrte Kehlkopf-Extirpation. Arch Klin Chirurgie 1874; 17: 343-56.

7. Sędziak J. Die bösartigen Geschwülste des Kehlkopfes und ihre Radicaalbehandlung. Wiesbaden 1897; 37.

8. Czerny V. Versuche ueber Kehlkopfekstirpation. Wien Med Wochenschr 1870; 20: 27.

9. Oertel M. Ueber Geschwulste im Keklkopf und deren Operation auf endolaryngealem Wege. Deutsch Arch Klin Med 1975; 25: 244 314, 504-37.

10. Maas H. Vollstandige Extirpation des Kehlkopfes. Tod nach 14 Tagen. Arch Klin Chir 1875; 19: 507-13.

11. Heine C. Resektion des Kehlkopfes bei Larynxstenose. Arch Klin Chir 1875; 19: 514-26.

12. Schmidt M. Totalextirpation des Kehlkopfes mit ungustigem Ausgange. Arch Klin Chir 1875; 18: 189-94.

13. Langenbeck BR. Totalextirpation des Kehlkopfs mit dem Zungenbein, einem Theil der Zunge, des Pharynx und Oesophagus. Berl Klin Woch 1875; 12: 453-5.

14. Matlakowski W. Excision of the cancroid affected larynx. Medycyna 1877; 5: 437-57.

15. Jawdyński F. A case of primary cervical carcinoma, the so called Volkmann's branchial cancer. The excision of the tumour together with the common and internal cartoid artery and the cartoid vein (in Polish). Wyzdrowienie. Gaz Lek 1888; 8: 530-7.

16. Crile GW. Excision of cancer of the head and neck with special reference to the plan of dissection based on one hundred and thirty two operations. JAMA 1906; 47: 1780-5.

17. Bien $\mathrm{S}$. The history of the radical operation on the neck lymph nodes - on the centenary of George Crile's publication (in Polish). Otolaryng Pol 2006; 40: 5-8.

18. Kierzek A. The development of Warsaw otolaryngological thought in the 19th century (in Polish). Wrocław 1997; 49-51.

19. Bień S, Kierzek A, Wojnar A. The achievements of Franciszek Ksawery Jawdyński (1851-1896) in the field of nose, throat and larynx surgery (in Polish). Otorynolaryng 2012; 11: 95-100.

20. Krajewski WH. Laryngeal cancer. Total laryngectomy (in Polish). Medycyna 1888/9; 17: 1-7, 19-24, 49-56, 65-7, 85-97, 105-10.

21. Sędziak J. On the treatment of laryngeal cancers (in Polish). Pam Tow Lek, Warsaw 1896; 42: 500.

22. Miodoński J, Spritzer M, Wadoń A. The treatment of the cancer of the larynx (in Polish). Pol Przeg Otolaryng 1939; 15: 407-48.

23. Składzień J, Olszewski E. The development of the surgical treatment of the cancer of the larynx (in Polish). Otolaryng Pol 1995; 49: 3-7.

24. Gussenbauer G. Ueber die erste durch Th. Billroth an Menschen und die Anwendung eines künstlichen Kehlkopfes. Arch Klin Chir 1887; 17: 14-7.

\section{Address for correspondence}

Prof. Andrzej Kierzek, DMSc

Rozbrat 5 m. 6

50-334 Wroclaw, Poland

tel. +48713221760

e-mail: andrzejkierzek@wp.pl

Submitted: 27.03.2013

Accepted: 15.09 .2013 